\title{
Improving the Experiment Report Writing Skills of Fifth Graders Through the Discovery Learning Method
}

\author{
Rita Indriyanti ${ }^{1}{ }^{*}$, Zuhdan Kun Prasetyo ${ }^{2}$ \\ ${ }^{1}$ Muhammadiyah Sapen Elementary School Yogyakarta. Jalan Bimokurdo No. 33, Sapen, \\ Gondokusuman, Daerah Istimewa Yogyakarta, 55221, Indonesia \\ ${ }^{2}$ Department of Science Education, Universitas Negeri Yogyakarta. Jalan Colombo No. 1, \\ Karangmalang, Yogyakarta, 55281, Indonesia. \\ *Corresponding Author. Email: rita_indriyanti@ymail.com, zuhdan@uny.ac.id \\ Received: 9 December 2017; Revised: 29 December 2017; Accepted: 8 January 2018
}

\begin{abstract}
This study aimed to improve the experimental report writing skills through the discovery learning method of the fifth graders of Muhammadiyah Sapen Elementary School Yogyakarta. This study was classroom action research. The subjects were 26 students of the fifth grade. The techniques for collecting data were observation, task, and documentation. The instruments of the data collection were observation sheets and writing performance. The result of this study showed that the process approach with the discovery learning method could improve the experimental report writing skills of the fifth-grade students of Muhammadiyah Sapen Elementary School Yogyakarta. It could be seen from the result of students' observation sheet and writing performance. The observation result indicated the increase of the process and result of experimental report writing skills with the average score of 74.88 in Cycle I to 89.38 in Cycle II. The percentage of the Minimum Criteria for Mastery Learning in Cycle I was 60\% and increased to $96 \%$ in Cycle II, with 24 the students achieved the mastery level and one failed. This showed that the students' classical mastery was achieved.
\end{abstract}

Keywords: writing skills, experimental report, discovery learning

How to Cite: Indriyanti, R., \& Prasetyo, Z. (2018). Improving the experiment report writing skills of fifth graders through the discovery learning method. Jurnal Prima Edukasia, 6(1), 102-110. doi:http://dx.doi.org/10.21831/jpe.v6i1.17284

Permalink/DOI: http://dx.doi.org/10.21831/jpe.v6i1.17284

\section{Introduction}

2013 Curriculum is designed to develop an implementation of three aspects, they are attitudes, knowledge, and skills. Based on this curriculum, a learning process in elementary school is conducted using a scientific approach. The scientific approach includes seeking information through observation, question-answer, experiments; processing data or information then presenting, analyzing, reasoning, and communicating them (Majid, 2014, p. 211).

Writing skill is the most difficult skill out of other three skills for the students (Iskandarwassid \& Sunendar, 2008, p. 291). Writing is an indirect communication form that needs deep thinking process. Writing skill is an inseparable part of the whole learning process that the students experience during their study at school. Writing requires skills; thus, it needs a continuous practice. Santrock (2007, p. 338) mentioned that a good writer takes many years and a lot of practices. Children must be given an extra room to write since their linguistic, cognitive skills and writing ones as well will be improved by giving them a proper teaching. Developing writing skill can be done gradually. The longer time it takes to develop the skill, the better skill the students might get in applying for correct grammar and sentence order. As mentioned in Tarigan (2008, p. 3), writing is a linguistic competence that is used to communicate directly or indirectly. It is inseparable activity from the whole learning process the students experience at school.

The learning process using 2013 Curriculum in experiment activities is often conducted to introduce their concepts and developments to the students. The students learning activity in conducting experiments strongly requires accuracy, determination, hard 
work, and creativity that support the results of their experiment. The students are expected to write a report about their experiment result. It needs the students' skill to write the experiment report and creativity in conducting the experiment so that the teacher is required to give a direct experience to his students. Writing the experiment report by the students is a part of daily linguistic skills. It supports the experiment report writing as a means to deliver messages and information to others. Language is utilized in expressing ideas, thoughts, feelings, and information to others, either in spoken or written forms. Writing activity in elementary school is an attempt to express the students' thoughts and feelings (Iskandarwasid \& Suhendar, 2015, p. 248).

The experiment report writing skill must be mastered by the students since it will improve their ability in communicating their experiment results to their peers and teacher. They will be able to comprehend learning materials well. In this research writing experiment report is a skill for writing experiences that the students have been through in conducting their experiment and later deliver them to others.

According to the students' experiment report writing results conducted in semester 1 academic year 2016/2017, the fifth graders in SD Muhammadiyah Sapen still had lack of experiment report writing skills. It was shown in their experiment report writing scores were below Minimum Learning Mastery Standard $(K K M)$ i.e. $\leq 75$. There were $84 \%$ of students who obtained the scores below KKM. They still had not dared to express the ideas they found in the experiments. The reports they wrote in an observation form still needs an improvement. They lacked analytical skill and their experiment report writing skill did not meet an observation report writing standard. It was due to the lack of learning process that involved students directly and insufficient experiment report result writing performed in the previous curriculum. The teacher had not found an appropriate method to improve the students' experiment report writing skills. He only presented the material according to the experiment being conducted, so that the students did not get used to writing the report for expressing their ideas and opinions according to the report writing the standard.

Based on the above descriptions, this research was about the use of discovery learning method. It was carried out since this method has been able to improve the writing skill as in previous studies conducted by Handoko (2015) that used it to improve the narratives writing skill, Sari \& Sukartiningsih (2014) that utilized it to improve the adventure stories writing skill.

The experiment report writing skill can be done through discovery learning method that is a discovery method in which the students can find something using their ideas and opinions, then they write systematically what they have observed in their experiment report with an absence of the teacher's help. According to Saab, van Joolingen, \& van Hout-Wolters (2007, p. 386), the discovery learning is the learning in which the students construct their own knowledge by experimenting on a domain and draw conclusions from their experiment result. Through this method, they can find some things when doing their experiment and directly write their new ideas and opinions in their experiment report according to the experiment report writing standard. It is supported by Bruner's statement in Schunk (2012, p. 280) that the discovery learning refers to the knowledge mastery for oneself in which this process involves hypothesis formulation and testing. The discovery process is one type of inductive reasoning where the students learn specific examples in formulating rules, concepts, and principles.

In this learning method, the teacher gives an opportunity to the students in scientific experiments. It should be followed by the students' experiment report writing activity in order to improve the students' ability in observing, collecting data, analyzing them, drawing conclusions, and communicating a certain problem. The students' ability in writing experiment reports will be developed later. A scientific thought in this learning will answer a problem and develop the students' ability in writing scientific papers in their future study.

In this research, the experiment report writing skill was improved using discovery learning method. The report writing using discovery learning method is the students systematically write what they have observed and found with an absence of the teacher's help in their experiment report. The learning in which the students can engage directly is able to give the 7 to 11-years-old children an ability to comprehend materials deeper. It is related to the concrete operational stage starting from 7 to 11 years of age. In this stage, the children start to recognize the concrete objects. In the formal operational stage starting from 11 years of age 
Jurnal Prima Edukasia, 6 (1), January 2018 -104

Rita Indriyanti, Zuhdan Kun Prasetyo

the children start to think formally and abstractly (Hergenhahn, Olson, \& Wibowo, 2010, pp. 318320).

After identifying those problems, this research focused on the fifth graders' experiment report writing and creative character skills in integrated thematic learning by using discovery learning method in Muhammadiyah Sapen Elementary School Yogyakarta. The problem found could be solved as stated in the formulation of problem i.e. how to improve the students' experiment report writing skills using discovery learning method for the fifth grade of CIMIPA Ibnu Haitham Muhammadiyah Sapen Elementary School Yogyakarta in academic year 2016/2017.

This research aimed to improve the students' experiment report writing skills using discovery learning method for the fifth grade of CIMIPA Ibnu Haitham Muhammadiyah Sapen Elementary School Yogyakarta in academic year 2016/2017. This research can be beneficial for students, teachers, and schools. The students will benefit from this research in order to improve their experiment report writing skill so that they can improve their understanding in learning and find new things. This research is also beneficial for teachers in correcting their teaching process and results, while for schools this research can improve their education quality and have professional teachers in conducting the teaching process.

\section{Method}

This research employed Classroom Action Research (CAR) using four steps or activities stated in Arikunto, Suhardjono, \& Supardi (2010, p. 42). They were (1) planning, (2) implementing, (3) observing, and (4) evaluating or reflecting. Figure 1 showed a flowchart of the CAR according to Arikunto et al. (2010).

The research was conducted in the even semester academic year 2016/2017 that was from March to April 2017 in the fifth graders of CIMIPA Ibnu Haitham Muhammadiyah Sapen Elementary School Yogyakarta. The subjects were the fifth graders of CIMIPA Ibnu Haitham that were 25 students in total comprising 10 boys and 15 girls.

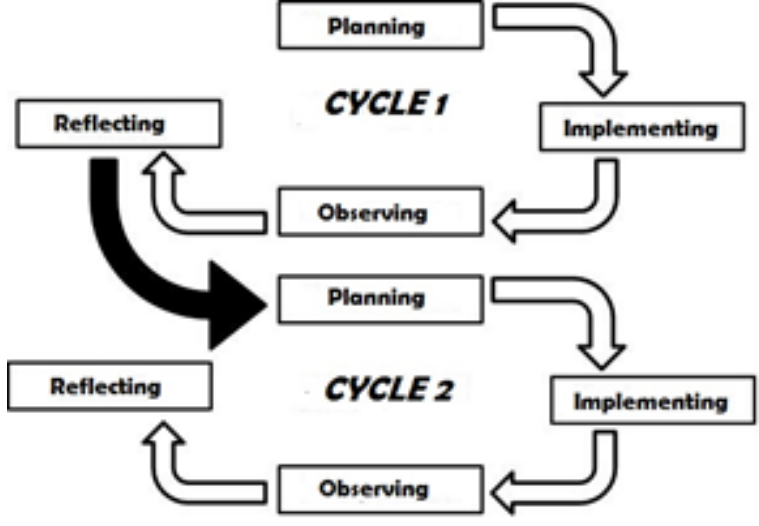

Figure 1. Classroom Action Research Cycles

The Classroom Action Research (CAR) used four steps stated in Arikunto et al. (2010, p. 42). They were (1) planning, (2) implementing, (3) observing, and (4) evaluating or reflecting. This CAR was conducted in two cycles. Each cycle was performed in one meeting. Following were explanations of those four activities. Firstly, in planning step the teacher arranged learning tools and instruments that would be used in the research. Secondly, in implementing step the learning was conducted using discovery learning steps i.e. stimulation, identification of problems, data collection, data processing, verification, and generalization. The third step was the observation that was conducted during the action implementation. The observation was conducted by two observers - the researchers and collaborating teacher. The observation focused on the implementation of discovery learning steps and experiment report writing skill. The fourth step was a reflection in which the researchers and collaborating teacher discussed learning evaluation that was conducted in cycle 1 . The reflection result became a basis for improvement in the next cycle.

Data collecting technique used in this study were observation, performance, and documentation. They were described as follows: (1) observation of the discovery learning method implementation, (2) students' performances that were in the form of experiment reports. The written reports became sources of assessment, (3) documentation used in this study was lesson plans, students' scores, and photos.

Data collecting instrument in this study used a rating scale of learning implementation observation and experiment report. Data obtained in this study were analyzed qualitatively.

The criteria determining the action' success in this research was when the students 


\section{Jurnal Prima Edukasia, 6 (1), January 2018 -105}

Rita Indriyanti, Zuhdan Kun Prasetyo

could achieve scores in their experiment report writing more than $\geq 75$ within the range 1-100 that was Minimum Learning Mastery Standard $(K K M)$. Classroom learning had met the mastery standard if the number of students who obtained the Minimum Learning Mastery Standard $(K K M)$ was $\geq 75$ from the total students. A change in the students' skills and attitudes after following the learning process using the discovery learning method could be seen from the observation data on their much better experiment report writing skills.

\section{Results and Discussion}

The researchers generated data related to the students' problems in the experiment report writing results from pre-research that was conducted in February 2017. The data became a problem that had to be solved in this research, that was some issues related to the scores of experiment report writing tasks in the pre-action stage. The highest score was 78,00 and the lowest one was 63,00 . Thus, the mean score was 68,50. It was still below Minimum Learning Mastery Standard (KKM) that was 75. The students' learning mastery reached $16 \%$ meaning that there were only 4 out of 25 students who could master the learning.

An attempt made to fix the problem was the discovery learning method. The method was used to improve the fifth graders' experiment report writing skills of Muhammadiyah Sapen Elementary School Yogyakarta.

\section{First Action Cycle Implementation}

First action cycle was conducted in one meeting. It occurred on 11 March 2016. The topic presented was properties of the magnet. The time allocation was $7 \times 35$ minutes.

\section{Planning}

The action research plan for properties of magnet learning material was done by preparing a lesson plan, experiment report sheet, video, and assessment instrument.

\section{Action}

The action taken in the first cycle was the teacher asked the students to do brainstorming at the beginning of the lesson. Then he delivered learning goals that must be met in the first cycle. He conducted the main activity using discovery learning method so that he performed the action in line with the implementation steps. In a stimulation stage, he played the video about the uses of the magnet in a daily life. The use of video by the teacher in natural science subject learning makes the students feel motivated in learning. Moreover, it results in an improvement in the students' learning cognitively as stated in Pebriani (2017, p. 20). The given stimulation enables the students to think for answering the teacher's questions. However, the students tended to be silent and were hesitant to answer or asked about the video.

In the problem identification step, the teacher gave an opportunity to the students to look for problem and ways to solve them. In this step, the students made an initial hypothesis. The teacher observed the students' activity related to their potentially emergent characteristics.

Data collecting step in the first cycle that was conducted by the teacher was proven to encourage the students learned actively by trying out, gathering information through group discussion. In this step, the teacher did not guide the students. The students were expected to find out the concept of properties of the magnet by themselves. The teacher was observing the students' activity by going around from group to group. In the data collecting and processing, the teacher led his students to try and prove the initial hypothesis. It was appropriate with Handika \& Wangid (2013, p. 92) that the problem-based learning can improve the students' learning skills in natural science subject by observing, grouping, predicting, drawing conclusions and communicating.

\section{Observation}

Based on the observation result, there were still some students who did not concentrate on the experiment they were doing. One student tended to play. Thus, the teacher always reminded and motivated the students to do the experiment seriously.

The generalization activity that was led by the teacher motivated the students to bravely report their experiment results in front of the class and divide their roles within their own group in responding other groups' questions. The teacher acted as a facilitator in this activity.

After the learning ended, the teacher evaluated the lesson by reflecting what was learned and completed from the beginning to the end of the lesson. The teacher conveyed what was considered hard for the students in the generalization activity. The teacher's activity after closing the lesson was assessing the 


\section{Jurnal Prima Edukasia, 6 (1), January 2018 -106}

Rita Indriyanti, Zuhdan Kun Prasetyo

students' experiment reports that were submitted. He gave the scores by giving a feedback on the students' experiment reports. He wrote some point for the students' improvement in writing the experiment report so that the students could figure out what they had to improve in their next report writing. This activity was supported by Ekinci (2017, p. 41) that through an interview the students mentioned error correction code and written feedback corrected the students' writing, and it improved their self-confidence. They also mentioned that they loved the error correction code and expected that the teacher could use the code in other classrooms. It can be inferred that the students show a positive attitude and thought towards the written correction and error correction code.

The observation was done for assessing the students and the teacher in the learning process. The learning implementation in the first cycle reached $82 \%$. Overall the learning implementation had been done successfully, yet the teacher lacked motivating the students to be actively engaged in each stimulation.

The students' experiment writing report skills in the first cycle showed the mean score 74,88 with the percentage of students'mastery was $60 \%$. The highest score was 84,00 and the lowest one was 59,00. The experiment report writing skills assessment involved some aspects. The assessment aspects were those that the students had to follow in writing their experiment report writing so that they were included in the experiment report format. They were a title, object and goals of the report, tools and materials, procedures, achieved result, theories, conclusion and references. The mean scores of each aspect were shown in Table 1.

Table1. The Mean Scores of Each Aspect in Experiment Report Writing Skill in The First Cycle

\begin{tabular}{clc}
\hline No. & \multicolumn{1}{c}{ Assessment Aspect } & Mean Score \\
\hline 1. & Title & 82,00 \\
2. & Object and Goals of Report & 80,00 \\
3. & Tools and materials & 72,00 \\
4. & Procedures & 73,00 \\
5. & Achieved result & 76,00 \\
6. & Theories & 73,00 \\
7. & Conclusion & 73,00 \\
8. & Reference & 70,00 \\
& Final Mean Score & $\mathbf{7 4 , 8 8}$ \\
\hline
\end{tabular}

The observation result in the students, experiment report writing skills in the first cycle showed that there was an improvement from the pre-action result. From the first cycle, the mean score was 74,36 with the percentage of students'mastery was $60 \%$. The highest score was 84,00 and the lowest one was 64,00 .

Based on the students' writing assignments using discovery learning method in the first cycle, the percentage of students' mastery still had not been able to reach the expected goal, that was $75 \%$. Acknowledging this shortcoming, an improvement was necessary to make in the next cycle.

\section{Reflection}

The reflection in the first cycle was done after the learning implementation. It could be shown in the stimulation step the teacher lacked motivating his students to actively participate in the question-answer and discussion session during the learning process in the stimulation, data collecting and processing steps performed by the students. Therefore, in the second cycle, the teacher made question cards to activate students in the stimulation step, he motivated the students in the data collecting process by discussing actively with their group members. There were some students who did not bring tools and materials for the experiment. Thus, in the second cycle, the teacher motivated the students and informed them the tools and materials a couple days prior to the experiment they were going to do.

\section{The Second Action Cycle Implementation}

The second action cycle was conducted on 21 March 2016. The topic presented was a making magnet. The time allocation was $7 \times 35$ minutes.

\section{Planning}

The researchers planned the second cycle of action research by preparing the teaching media that were going to be used in the class. They were question cards on folding paper, tools and materials needed to make magnets, video about magnets that was going to be used in the stimulation stage, experiment report sheets that were going to be distributed to the students, research instruments, lesson plan related to the material and the improvement on the learning process in the second cycle.

Action

The teacher presented learning goals that the students were going to achieve so that they knew what they were going to learn. The teacher 


\section{Jurnal Prima Edukasia, 6 (1), January 2018 -107}

Rita Indriyanti, Zuhdan Kun Prasetyo

delivered learning steps that were going to be conducted using the discovery learning method as following:

Stimulation step that was delivered by the teacher to the students related to a prior knowledge of the magnet. The students paid attention to the video being played on the making of magnets by the teacher, then they observed, identified (words, terms, and contents of the video) and watched it until finished. The students wrote questions on the question cards based on the contents of the video. Later the students exchanged their question cards with their peers and asked them to answer the questions. Some students actively participated in the question-and-answer session using the question cards.After the question cards activity finished, the student gave the assignment to make the magnet using the tools and materials prepared before.

After watching the video on the making of magnets, the students identified problems that might be emerged in the making of magnets. They did an experiment for making the magnet. They made the magnet using the tools and materials they brought.

Data were collected when the students did the experiment to make the magnet in three ways. The students began doing the experiment using the tools and materials that were gathered to make the magnet by rubbing, an induction and an electromagnet. The students in group attempted to do the experiment to find ways to make the magnet. The students observed, gave a try, analyzed the experiment results by having a discussion. In line with the study conducted by Klein \& Ehrhardt $(2015$, p. 53) the discussion has double-edged effects on reasoning. The discussion reduced bias in claims and conclusions. It was consistent with the previous research showing that the discussion aimed to produce more dialectical arguments.

In data processing activity, the students tried to proceed the data obtained previously. They proceeded the data from those three ways of making the magnet. They were asked to write their experiment result of making the magnet in a report discussion column.

The students verified their experiment result by looking for information in the reference book. They compared their experiment result to existing theories in the book.

The students wrote conclusions for their experiment on the three ways of magnet made in the conclusion report sheet. Then they presented it in front of the classroom. They presented their experiment results in a group. Having evenly distributed workload, each group member was able to participate actively in responding questions from other groups. In the generalization activity the question-and-answer an discussion on each group's experiment report result occurred. The discussion indeed could broaden the students' knowledge of the learned materials. According to a study by Tonissen, Lee, Woods, \& Osborne (2010, p. 10) the students could evaluate their own performance and it could make them adapt and improve the expected standard. Later they would be acknowledged and contented for their success in completing the task and the writing assignment. Continous feedbacks strengthened their concepts that led to their improved self-confidence and skill in completing the writing assignment.

\section{Observation}

The observation result on the implementation of learning conducted by the teacher in the second cycle showed the learning implementation reached $93 \%$. Generally, the obtained result was implemented well and the learning goals had been achieved.

The performance result of experiment report writing skill in the second cycle showed the mean score was 89,38 with the percentage of students'mastery was $96 \%$. The highest score was 97,00 and the lowest one was 72,00 .

There was an improvement in the mean scores of experiment report writing skill in each observation aspect. It occurred because the teacher had improved each step of learning process using the discovery learning method. The teacher improved his ways in motivating his students in the stimulation, data collecting, and generalization steps so that the students did not find any difficulties in expressing their thoughts and ideas when they were doing their experiment until finished. They were able to write their experiment report result from each stage they were experiencing and achieved the scores above Minimum Learning Mastery Standard $(K K M)$. The mean scores of each aspect in the report writing were shown in Table 2.

The learning process in the first cycle showed the students' mastery of the experiment report writing skills reached $60 \%$. It was because there were some students who found difficulties in writing some aspects of the report such as the complete tools and materials, the conclusions and references related to the 


\section{Jurnal Prima Edukasia, 6 (1), January 2018 -108}

Rita Indriyanti, Zuhdan Kun Prasetyo

experiment pictures. While in the learning process in the second cycle the teacher did the improvement from the problems occurred in the previous cycle. He motivated his students related to their activeness, tools, and materials for the experiment, and conclusion writing so that their experiment report writing skill mastery could be improved until it reached $96 \%$.

Table 2. The Mean Scores of Each Aspect in Experiment Report Writing Skill in The Second Cycle

\begin{tabular}{clc}
\hline No. & \multicolumn{1}{c}{ Assessment Aspect } & Mean Score \\
\hline 1. & Title & 95,00 \\
2. & Object and Goals of Report & 92,00 \\
3. & Tools and materials & 90,00 \\
4. & Procedures & 90,00 \\
5. & Achieved result & 81,00 \\
6. & Theories & 94,00 \\
7. & Conclusion & 89,00 \\
8. & Reference & 84,00 \\
& Final Mean Score & \\
\hline
\end{tabular}

The percentage increase of experiment report writing skill mastery is shown in Figure 2.

The Percentage Increase of Experiment Report Writing Skill Mastery

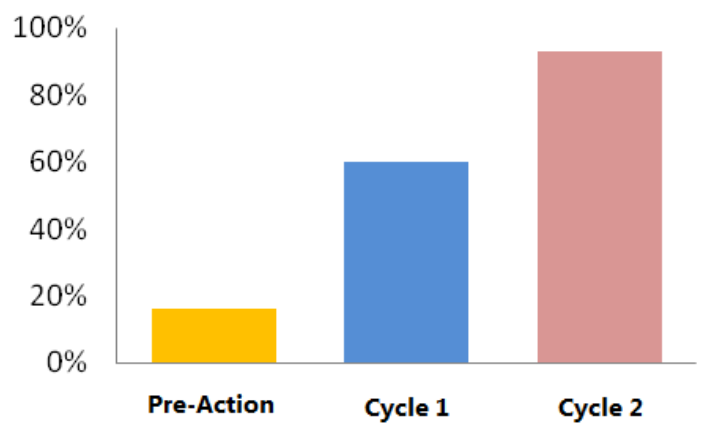

Figure 2. The Percentage Increase of Experiment Report Writing Skill Mastery

Based on Figure 2, it could be seen that there was an increase in the percentage increase of Minimum Learning Mastery Standard (KKM) from Pre-Action $16 \%$ to Cycle $160 \%$ to Cycle 2 $96 \%$. The discovery learning method used was able to increase the percentage of experiment report writing skill mastery since its steps were able to improve the students' understanding in writing the experiment report. According to Dahar (2012, p. 80) stated that the knowledge gained from the experiment learning had a strength i.e the student's knowledge would last longer or easy to memorize compared to the knowledge gained from other ways.

Discussion
The learning process using the discovery learning method covered stimulation, problems identification data collecting and processing, verification, and generalization activities. The observation result on the implementation of learning conducted by the teacher in the first cycle showed the success rate reached $82 \%$ and increased to $93 \%$ in the second cycle. It occurred because the teacher had improved the learning process in the stimulation and data collecting steps using the discovery learning method.The teacher used the question card in the stimulation step so that the students were actively involved in the question-and-answer session. He also gave rewards for his students who brought complete tools and materials so that the data collecting step could run successfully.

The students' experiment report writing skills using the discovery learning method had improved from the pre-action to the first cycle and the second cycle. The skill aspects in writing the experiment report that covered the title, goals of the report, tools and materials, procedures, achieved results, theories, conclusion, and references were able to lead the students in improving their experiment report writing skills systematically.

The assessment of experiment report writing skills covered some aspects as follows. First, the title. In this aspect, the students' title was assessed by its appropriateness to the report content, its correct spelling, and punctuation. Second, the experiment goals. In this aspect, the students wrote the experiment goals they were going to do. Third, the tools and materials aspect. The students write the completeness of tools and materials they were using for the experiment. Fourth, the procedures. The students wrote the steps they were doing in the experiment so that they could achieve intended goals. Fifth, the experiment results. The students wrote what results they obtained from the experiment. Sixth, theories. The students wrote the theories form the experiment materials they did so that they could know the theoretical bases or the lessons they learned by comparing whether those theories matched with the practices they did. Seventh, the generalization. The students drew conclusions from the experiment results. Eighth, references. The references contained the pictures of the students' experiment results. By doing it so, the students could improve their skills in writing the experiment report. It was supported by Azmussya'ni \& 
Wangid (2014, p. 9) that the use of pictures could improve the students; writing skills. Those eight aspects were a set of points in assessing the fifth graders' experiment report writing skills.

The discovery learning method that was used was able to improve the fifth graders' experiment report writing skills. The reason was its steps could lead the students to follow each procedure in writing the experiment report. As stated in Balım (2009, p. 16) that by using the discovery learning method, the students were actively engaged in the learning process and improve the learning success as it obliged them by delivering their opinions related to the concepts, information, and events. It was done by discussing and asking questions so that the students could find solutions through their active participation. The discover learning method was one of the various teaching methods that could make the students and teacher active so that it could improve the students' success and skills if compared to the traditional teaching method. As Bruner in Ellis (2010, p. 55) said that Bruner made some significant claims on the learning inventions as follows; (1) Learning using senses as a direct encounter with the knowledge. Bruner also thought that the students experienced a success ad an inventor, and gained benefits from their ability in learning as well. As these skills were developing, the students would be more able to manage their thinking process conceptually, (2) The discovery learning was related to the reward. Bruner considered that discovery was a useful process, (3) In the discovery learning process, strategies to learn effectively would appear automatically, (4) The discovery learning was related to the memory. A combination of symbolic, ionic and enactive representations that occurred in the discovery learning enables the students to conceptualize what they had learned.

The students' experiment report writing skills gradually improved through the use of discovery learning method that was in line with a finding (Mahmoud, 2014, p. 152) that the learning strategy using the discovery learning method helped to recruit activities in which the students learnt for themselves and were able to apply what they got in a new situation, and finally they could produce an effective learning. Robinson, Dailey, Hughes, \& Cotabish (2014, p. 5) stated that curriculum could provide an opportunity for the students to apply a scientific reasoning, be encouraged in reflection and collaboration, be engaged in the problem solving qualitatively and be exposed in the real works of scientists. Thus, the implementation of discovery learning method in curriculum used by the school could give synergy in developing the students' writing skills in the education world, especially in the elementary school.

\section{Conclusion}

The discovery learning method used in the integrated thematic learning could improve the fifth graders' experiment report writing skills in Muhammadiyah Sapen Yogyakarta Elementary School. It was shown by the mean score in the experiment report writing skill gradually increased from 68,50 in the pre-action to 74,88 in the first cycle and 89,38 in the second cycle.

The discovery learning method used in the integrated thematic learning could improve the students' mastery of the expected Minimum Learning Mastery Standard (KKM). It could be seen from their results in Cycle 2 that was $96 \%$ with the Minimum Learning Mastery Standard $(K K M)$ was 75.

The suggestions in this research were (1) for school, it can motivate the teacher to use various methods in the learning process, (2) for teachers, it can increase the percentage of students' mastery in writing the experiment report as much as $96 \%$. It was because there were some students who had not been successful in producing the report. Thus, it is suggested for the teacher to motivate the students in each learning steps in order to achieve the students' mastery level until 100\%.

\section{References}

Arikunto, S., Suhardjono, \& Supardi. (2010). Penelitian tindakan kelas. Jakarta: Bumi Aksara.

Azmussya'ni, A., \& Wangid, M. N. (2014). Peningkatan keterampilan menulis menggunakan pendekatan proses dengan media gambar di SDN 3 Sakra. Jurnal Prima Edukasia, 2(1), 1. https://doi.org/10.21831/jpe.v2i1.2640

Balım, A. G. (2009). The effects of discovery learning on students' success and inquiry learning skills. Eurasian Journal of Educational Research Egitim Arastirmalari-Eurasian Journal of Educational Research, 35(35), 1-20. Retrieved from 


\section{Jurnal Prima Edukasia, 6 (1), January 2018 -110}

Rita Indriyanti, Zuhdan Kun Prasetyo

http://www.ejer.com.tr/0DOWNLOAD/p dfler/eng/1177009234.pdf

Dahar, R. W. (2012). Teori-teori belajar \& pembelajaran. Jakarta: Erlangga. https://doi.org/2012

Ekinci, M. (2017). An action research: The effect of written corrective feedback and error codes in improving writing skill. International Online Journal of Teachers in Collaboration, 1(1), 31-47.

Ellis, A. K. (2010). Teaching and learning elementary social studies. Boston: Pearson/Allyn \& Bacon.

Handika, I., \& Wangid, M. N. (2013). Pengaruh pembelajaran berbasis masalah terhadap penguasaan konsep dan keterampilan proses sains siswa kelas V. Jurnal Prima Edukasia, $\quad$ 1(1), 85-93. https://doi.org/10.21831/jpe.v1i1.2320

Handoko, D. (2015). Peningkatan keterampilan menulis wacana narasi dengan model pembelajaran discovery learning pada peserta didik kelas X TKJ SMK PGRI 2 Kebumen tahun pelajaran 2014/2015. ADITYA - Pendidikan Bahasa Dan Sastra Jawa, 7(3), 77-84. Retrieved from http://ejournal.umpwr.ac.id/index.php/adit ya/article/view/2432

Hergenhahn, B. R., Olson, M. H., \& Wibowo, T. (2010). Theories of learning (Teori belajar). Jakarta: Kencana Prenada Media Group.

Iskandarwassid \& Sunendar, D. (2008). Strategi pembelajaran bahasa. Bandung: PT Remaja Rosdakarya.

Klein, P. D., \& Ehrhardt, J. S. (2015). The effects of discussion and persuasion writing goals on reasoning, cognitive load, and learning. Alberta Journal of Educational Research, 61(1), 40-64. Retrieved from http://ajer.journalhosting.ucalgary.ca/inde x.php/ajer/article/view/1494/pdf

Mahmoud, A.-R. K. A.-R. (2014). The effect of using discovery learning strategy in teaching grammatical rules to first year general secondary student on developing their achievement and metacognitive skills. International Journal of Innovation and Scientific Research, 5(2), 146-153. Retrieved from http://www.ijisr.issrjournals.org/abstract.php?article=IJISR-
14-153-06

Majid, A. (2014). Pembelajaran tematik terpadu. Bandung: Remaja Rosda Karya.

Pebriani, C. (2017). Pengaruh penggunaan media video terhadap motivasi dan hasil belajar kognitif pembelajaran IPA kelas V. Jurnal Prima Edukasia, 5(1), 11. https://doi.org/10.21831/jpe.v5i1.8461

Robinson, A., Dailey, D., Hughes, G., \& Cotabish, A. (2014). The effects of a science-focused STEM intervention on gifted elementary students' science knowledge and skills. Journal of Advanced Academics, 25(3), 189-213. https://doi.org/10.1177/1932202X145337 99

Saab, N., van Joolingen, W. R., \& van HoutWolters, B. H. A. M. (2007). Supporting communication in a collaborative discovery learning environment: The effect of instruction. Instructional Science, 35(1), 73-98. https://doi.org/10.1007/s11251-006-90034

Santrock, J. W. (2007). A topical approach to life-span development. New York, NY.: McGraw-Hill Companies, Inc.

Sari, V. N., \& Sukartiningsih, W. (2014). Penerapan model discovery learning sebagai upaya meningkatkan kemampuan menulis teks cerita petualangan siswa kelas IV sekolah dasar. Jurnal Penelitian Pendidikan Guru Sekolah Dasar, 2(2), 1$10 . \quad$ Retrieved from http://jurnalmahasiswa.unesa.ac.id/index. php/jurnal-penelitianpgsd/article/view/10660

Schunk, D. H. (2012). Learning theories: An educational perspective. Pearson.

Tarigan, H. G. (2008). Menulis sebagai suatu keterampilan berbahasa. Bandung: Angkasa.

Tonissen, K. F., Lee, S. E., Woods, K. J., \& Osborne, S. A. (2010). International journal of innovation in science and mathematics education IJISME. International Journal of Innovation in Science and Mathematics Education (Formerly CAL-Laborate International), 22(4). Retrieved from https://openjournals.library.sydney.edu.au /index.php/CAL/article/view/7564 